\title{
Enhancement of Human Granulopoiesis In Vitro by Biosynthetic Insulin-like Growth Factor I/Somatomedin C and Human Growth Hormone
}

\author{
Shoshana Merchav, " llana Tatarsky," and Zeev Hochberg ${ }^{\ddagger}$ \\ ${ }^{*}$ Department of Hematology, Faculty of Medicine, Technion-Israel Institute of Technology and Rambam Medical Center; ${ }^{\ddagger}$ Department \\ of Pediatrics, Rambam Medical Center; Department of Pharmacology, Faculty of Medicine and Rappaport Family Institute for \\ Research in the Medical Sciences, Technion-Israel Institute of Technology, Haifa, Israel
}

\begin{abstract}
The effect of biosynthetic recombinant insulin-like growth factor I/somatomedin C (IGF-I/Sm-C) and human growth hormone (hGH) on the in vitro growth and maturation of human marrow myeloid progenitors was investigated. Myeloid colony formation was maximally enhanced by $60 \mathrm{ng} / \mathrm{ml}$ IGF-I/Sm-C and by $250 \mathrm{ng} / \mathrm{ml} \mathrm{hGH}$, resulting in an increase in colony numbers of $41 \pm 7$ and $38 \pm 4 \%$, respectively $(P<0.001)$. Both peptides induced a 1.5-2.5-fold increase in the frequency of colonies composed of granulocytes alone, but did not alter the numbers of monocyte/macrophage or mixed granulocyte/macrophage colonies. IGF-I/Sm-C and hGH were also found to enhance myeloid maturation towards mature granulocytes in suspension cultures of human marrow cells. The effect of both peptides on human marrow granulopoiesis was similarly demonstrable in serum-free cultures stimulated with human recombinant granulocyte/macrophage colony-stimulating factor. Enhancement of human marrow granulopoiesis in vitro by hGH required the presence of marrow adherent cells and was abrogated by specific monoclonal antibodies directed against IGF-I/Sm-C receptors. The effect of hGH on marrow myeloid progenitors thus appears to be mediated by paracrine IGF-I/Sm-C.
\end{abstract}

\section{Introduction}

The insulin-like growth factors (IGFs) ${ }^{1}$ are peptide growth factors sharing close structural homology with proinsulin (1), which stimulate mitogenesis and metabolic processes in a variety of cell types (2). In humans, two IGF peptides have been fully sequenced and cloned $(3,4)$. IGF-I/somatomedin C (IGF-I/Sm-C) is the presumed paracrine or autocrine mediator of growth hormone in peripheral tissues (5), and IGF-II, a

Address correspondence to Dr. Merchav, Dept. of Hematology, Faculty of Medicine, Technion-Israel Institute of Technology, P.O.B. 9649, Haifa 31096, Israel.

Received for publication 7 November 1986 and in revised form 28 September 1987.

1. Abbreviations used in this paper: ANA-esterase, $\alpha$-naphthylacetate esterase; ANOVA, one-way analysis of variance; CSF, colony-stimulating factor; GM-CFU, granulocyte/macrophage CFUs; GM-CSF, granulocyte/macrophage CSF; hGH, human growth hormone; IGF, insulin-like growth factor; IGF-I/Sm-C, IGF-I/somatomedin C; MoCM, Mo-conditioned medium.

J. Clin. Invest.

(C) The American Society for Clinical Investigation, Inc.

0021-9738/88/03/0791/07 \$2.00

Volume 81, March 1988, 791-797 less potent growth factor, is more insulin-like in its mode of action (6).

Membrane receptors for IGF-I/Sm-C have been detected on various mammalian cells (7-10), including human hemopoietic cells such as erythrocytes (11) and myeloid leukemic cells (12). IGF-I/Sm-C has recently been shown to enhance colony formation in vitro by human primitive and relatively mature marrow erythroid progenitors (13), an effect also known to be induced by human growth hormone (hGH) $(14,15)$.

The purpose of the present study was to investigate the effect of biosynthetic IGF-I/Sm-C on the growth and maturation of cultured human marrow myeloid progenitors (granulocyte/macrophage CFU [GM-CFU]) and to compare it to the effect of biosynthetic hGH. The possible role of IGF-I/Sm-C as a mediator of $\mathrm{hGH}$ was examined by the use of a monoclonal antibody directed against IGF-I/Sm-C receptors.

\section{Methods}

Preparation of marrow cells. Human bone marrow, obtained by informed consent from hematologically normal patients undergoing open-heart surgery, was aspirated into heparinized syringes. Marrow aspirates were diluted threefold in HBSS and subjected to Ficoll-Hypaque gradient centrifugation. The mononuclear cells were washed three times in HBSS and resuspended for culturing.

Removal of marrow adherent cells. Adherent cells were removed by incubating $5 \times 10^{6} / \mathrm{ml}$ marrow mononuclear cells in HBSS plus $20 \%$ FCS in plastic Petri dishes (Nunc, Copenhagen, Denmark) for $3 \mathrm{~h}$ at $37^{\circ} \mathrm{C}$ in a fully humidified atmosphere of $7.5 \% \mathrm{CO}_{2}$ in air. Nonadherent cells, containing $2 \pm 1 \%(n=3)$ monocytes, as determined by $\alpha$ naphthylacetate esterase (ANA-esterase) staining, were collected, washed three times in HBSS, and resuspended for culturing. Marrow adherent cells consisted of $89 \pm 3 \%$ monocytes.

Colony assay. Marrow mononuclear cells, at a concentration of 1 $\times 10^{5}$ cells $/ \mathrm{ml}$, were cultured in $1 \mathrm{ml}$ modified Dulbecco's medium (16) supplemented with $10 \%$ FCS, $10 \mathrm{mg} / \mathrm{ml} \mathrm{BSA} \mathrm{(Sigma} \mathrm{Chemical}$ Co., St. Louis, MO), $4 \times 10^{-6} \mathrm{M}$ human transferrin (Behring-Werke, Marburg, FRG) saturated with $\mathrm{FeCl}_{3}, 1 \times 10^{-7}$ selenite (Merck, Darmstadt, FRG), $1 \times 10^{-3}$ nucleosides (Sigma Chemical Co.), and 1.5 $\times 10^{-5} \mathrm{M}$ each cholesterol and linoleic acid (Sigma Chemical Co.), using $0.3 \%$ agar (Difco Laboratories, Detroit, MI) as a semisolid agent. The level of IGF-I/Sm-C in culture medium containing all of the above constituents was $11 \mathrm{mU} / \mathrm{ml}$. The level of $\mathrm{hGH}$ was $<0.1 \mathrm{ng} / \mathrm{ml} .1-\mathrm{ml}$ cultures were set up in 35- $\times 10$-mm plastic Petri dishes (Falcon Plastics, Cockeysville, MD). As indicated, cultures were stimulated with Mo-conditioned medium (MoCM) as a source of GM colony-stimulating factor (GM-CSF) (17) or with 200 pM human recombinant GMCSF (18), the latter kindly provided by Dr. Judith Gasson, UCLA School of Medicine, Los Angeles, CA. Various concentrations of IGF-I/Sm-C and hGH were added at the initiation of culture. Cultures were incubated at $37^{\circ} \mathrm{C}$ in a fully humidified atmosphere of $7.5 \% \mathrm{CO}_{2}$ in air. Colonies of $>50$ cells were scored on the 14th $d$ of culture.

Determination of colony types. An in situ staining technique in 
sequence for ANA-esterase (monocytes/macrophages) and naphtholAS-D-chloroacetate esterase (granulocytes), performed as previously described (19), permitted typing of various colonies within the same culture dish.

Suspension cultures. Marrow mononuclear cells, at $0.5 \times 10^{6}$ cells/ $\mathrm{ml}$, were grown under virtually the same culture conditions as those used for the colony assay, except for the omission of agar. The cells were plated in $1 \mathrm{ml}$ vol in 24-well dishes (Nunc) containing $200 \mathrm{pM}$ recombinant GM-CSF and various concentrations of IGF-I/Sm-C or hGH. Cultures were incubated at $37^{\circ} \mathrm{C}$ in a fully humidified atmosphere of $7.5 \% \mathrm{CO}_{2}$ in air. After $7 \mathrm{~d}$, the cells were cytocentrifuged, stained with Wright-Giemsa, and examined microscopically for 200cell differential counts.

$I G F-I / S m-C$ and $h G H$. Biosynthetic (recombinant) human IGF-I/ Sm-C (1 U/200 ng) and hGH were a gift from KabiVitrum, Stockholm, Sweden. The purity of IGF-I/Sm-C and hGH was 90 and $99 \%$, respectively. Both peptide preparations were diluted in culture medium containing $0.1 \% \mathrm{BSA}$ and added to the dishes at the initiation of culture.

Anti-IGF-I/Sm-C receptor monoclonal antibodies. An anti-IGF-I/ Sm-C receptor monoclonal antibody, $\alpha \mathrm{IR}-3$ (20), was kindly provided by Prof. J. J. Van Wyk, University of North Carolina, Chapel Hill, NC. It was added at the initiation of culture at a final concentration of 15 $\mu \mathrm{g} / \mathrm{ml}(100 \mathrm{nM})$. The addition of IGF-I/Sm-C and hGH to cultures containing $\alpha$ IR-3 was delayed for $2 \mathrm{~h}$.

Statistics. Statistical analyses were performed using Student's $t$ test or a one-way analysis of variance (ANOVA). Significance was defined as $P<0.05$.

\section{Results}

Enhancement of colony formation by IGF-I/Sm-C and $h G H$. IGF-I/Sm-C enhanced the formation of colonies by human marrow GM-CFU (Fig. 1). Assayed in cultures stimulated with a saturating dose of $\mathrm{MoCM}$, a significant increase in colony frequency was already detected at $6 \mathrm{ng} / \mathrm{ml} \mathrm{(30} \mathrm{mU/ml)} \mathrm{IGF-I/}$ Sm-C (131 $\pm 8 \%$ of control GM-CFU frequency; $P<0.001)$. Maximal enhancement of colony formation ( $141 \pm 7 \%$ of control GM-CFU frequency) was observed at $60 \mathrm{ng} / \mathrm{ml}$ (300 mU) IGF-I/Sm-C (ANOVA, $P<0.005$ ). Significant enhancement of human marrow GM-CFU by hGH (Fig. 2) was detected at a concentration of $150 \mathrm{ng} / \mathrm{ml}$ (129 $\pm 14 \%$ of control GM-CFU; $P$ $<0.03$ ), being maximal (138 $4 \%$ of control GM-CFU) at 250 $\mathrm{ng} / \mathrm{ml}$ (ANOVA, $P<0.005$ ).

Enhancement of human marrow myeloid colony forma-

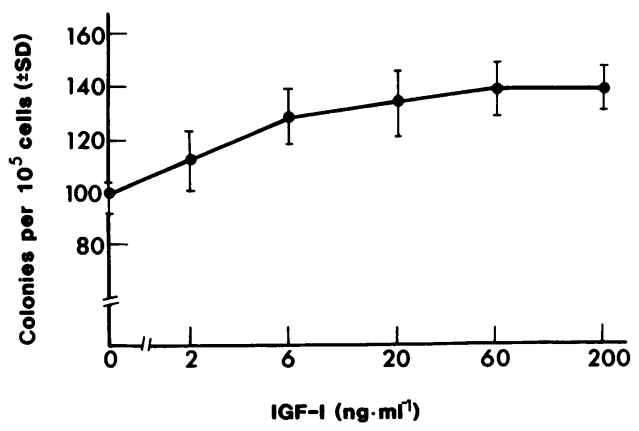

Figure 1. Effect of biosynthetic IGF-I/Sm-C on human marrow myeloid colony formation in vitro. Cultures were stimulated with $5 \%$ MoCM. No colonies grew in the absence of CSF. Results represent the mean $\pm S D$ of four independent experiments, performed in triplicates.

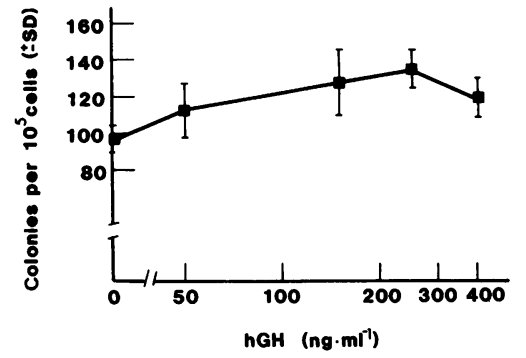

Figure 2. Effect of biosynthetic hGH on human marrow myeloid colony formation in vitro. Legends as in Fig. 1.

tion by IGF-I/Sm-C and hGH was also detected in serum-free cultures stimulated with human recombinant GM-CSF (Table I). Although fewer colonies were detected under these culture conditions, elimination of serum did not significantly alter the concentration-dependent magnitude of colony enhancement induced by IGF-I/Sm-C and hGH. Myeloid colony formation was significantly enhanced in cultures stimulated with combined limiting concentrations of both IGF-I/Sm-C $(2 \mathrm{ng} / \mathrm{ml})$ and hGH $(50 \mathrm{ng} / \mathrm{ml})(P<0.05)$, whereas combined maximal concentrations of both peptides did not exert an additive effect. The enhancement of myeloid colony formation in these cultures did not differ in magnitude from that observed in cultures stimulated with crude MoCM (Figs. 1 and 2).

Interactions between IGF-I/Sm-C, $h G H$, and CSF. The mode of action of IGF-I/Sm-C and hGH in relation to CSF was evaluated by studying the effect of both peptides on colony formation by GM-CFU at various concentrations of MoCM, used as a source of CSF. As shown in a representative experiment (Fig. 3), IGF-I/Sm-C and hGH enhanced the growth of human marrow GM-CFU at both limiting and saturating concentrations of MoCM (Fig. $3 \mathrm{~A}$ ), but did not alter the re-

Table I. Enhancement of Myeloid Colony Formation by IGF-I/Sm-C and hGH in Serum-free Cultures Stimulated with Human Recombinant GM-CSF

\begin{tabular}{|c|c|c|}
\hline \multirow[b]{2}{*}{ Additive } & \multicolumn{2}{|c|}{ Colonies per $10^{5}$ cells $( \pm \mathrm{SD})$} \\
\hline & Serum free & Serum supplemented \\
\hline- & $41 \pm 4(100)^{\ddagger}$ & $108 \pm 8 \quad(100)$ \\
\hline IGF-I/Sm-C (2 ng/ml) & $45 \pm 5(110 \pm 5)$ & $120 \pm 5 \quad(111 \pm 9)$ \\
\hline IGF-I/Sm-C (6 ng/ml) & $58 \pm 4(138 \pm 8)$ & $142 \pm 6 \quad(131 \pm 6)$ \\
\hline IGF-I/Sm-C (200 ng/ml) & $62 \pm 5(151 \pm 6)$ & $149 \pm 9 \quad(138 \pm 8)$ \\
\hline $\mathrm{hGH}(50 \mathrm{ng} / \mathrm{ml})$ & $46 \pm 4(112 \pm 5)$ & $122 \pm 6 \quad(113 \pm 4)$ \\
\hline $\mathrm{hGH}(150 \mathrm{ng} / \mathrm{ml})$ & $53 \pm 6(129 \pm 5)$ & $136 \pm 9 \quad(126 \pm 3)$ \\
\hline $\mathrm{hGH}(250 \mathrm{ng} / \mathrm{ml})$ & $59 \pm 4(144 \pm 6)$ & $145 \pm 6 \quad(134 \pm 6)$ \\
\hline \multicolumn{3}{|l|}{ IGF-I/Sm-C (2 ng/ml) } \\
\hline$+\mathrm{hGH}(50 \mathrm{ng} / \mathrm{ml})$ & $52 \pm 5(122 \pm 4)$ & $130 \pm 6 \quad(120 \pm 5)$ \\
\hline \multicolumn{3}{|l|}{ IGF-I/Sm-C $(200 \mathrm{ng} / \mathrm{ml})$} \\
\hline$+\mathrm{hGH}(250 \mathrm{ng} / \mathrm{ml})$ & $60 \pm 5(146 \pm 6)$ & $150 \pm 13(139 \pm 7)$ \\
\hline
\end{tabular}

Cultures were stimulated with 200 pM human recombinant GMCSF. The number of colonies in the absence of GM-CSF was 0 and $12 \pm 2$ per $10^{5}$ cells in the absence and presence of serum, respectively. Results represent the mean $\pm S D$ of three independent experiments, performed in triplicates.

* Supplemented with $10 \%$ FCS.

${ }^{\ddagger}$ Numbers in parentheses indicate percent mean $( \pm S D)$ colony frequency. 


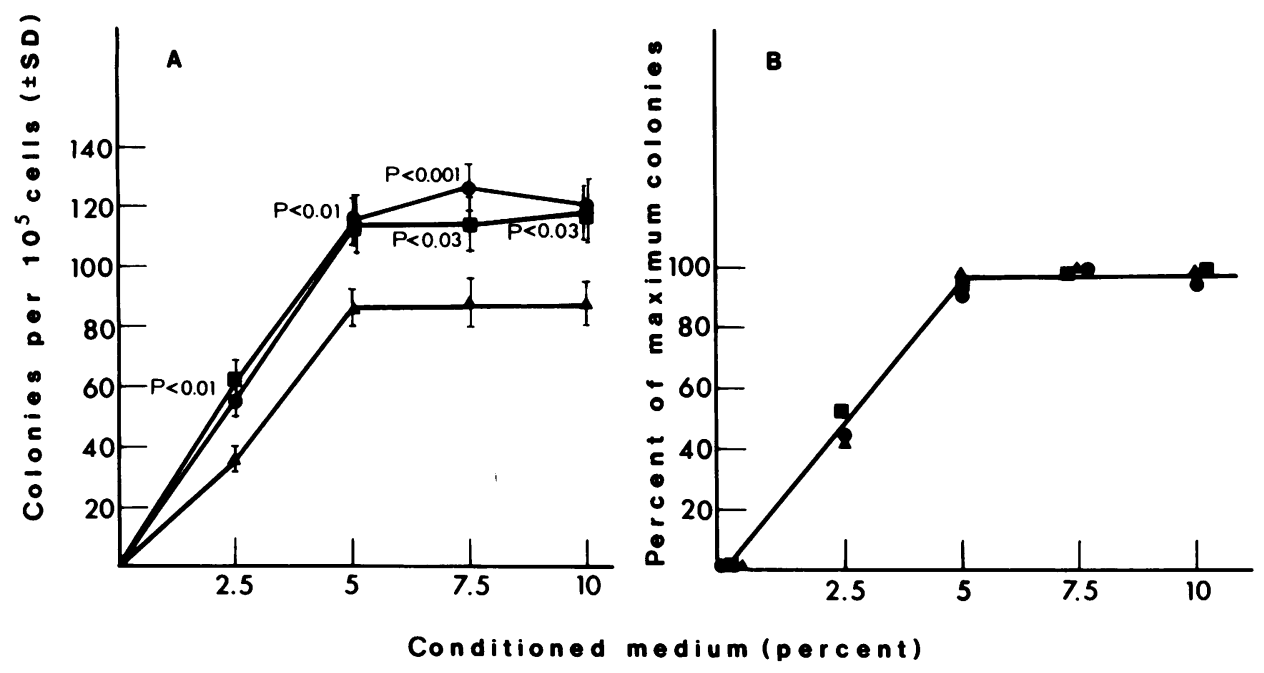

Figure 3. IGF-I/Sm-C and hGH in relation to CSF. $(A)$ Absolute colony frequency. (B) Percentage of maximum colonies. Cultures stimulated with MoCM as a source of CSF ( $\triangle$ ) were supplemented with either $200 \mathrm{ng} / \mathrm{ml} \mathrm{IGF-I/Sm-C} \mathrm{( \bullet )} \mathrm{or} \mathrm{with} 250 \mathrm{ng} / \mathrm{ml} \mathrm{hGH}$ ( $\bullet$ ). No colonies grew in the absence of CSF. Results represent the mean \pm SD of triplicate cultures.

sponsiveness of these progenitors to stimulation with CSF (Fig. $3 B$ ). In addition, neither IGF-I/Sm-C nor hGH stimulated any colony formation when added in the absence of CSF to the cultures.

Colony types in cultures stimulated with IGF-I/Sm-C and $h G H$. Colony formation by GM-CFU results in the appearance of colonies that are composed of granulocytes, monocytes/macrophages, or both cell types (19). Using in situ stain- ing techniques to determine colony composition, we examined the frequency of colony types that had developed in marrow cell cultures in the presence of various concentrations of IGF-I/Sm-C or hGH. As shown in Table II, both IGF-I/Sm-C $(2-200 \mathrm{ng} / \mathrm{ml})$ and $\mathrm{hGH}(50-250 \mathrm{ng} / \mathrm{ml})$ induced a significant $(\sim 1.5-2.5$-fold $)$ increase in the number of colonies consisting only of granulocytes, whereas the total numbers of monocyte/ macrophage or mixed granulocyte/macrophage colonies re-

Table II. Enhancement of Granulocyte Colony Formation by IGF-I/Sm-C and hGH

\begin{tabular}{|c|c|c|c|c|}
\hline \multirow[b]{2}{*}{ Additive } & \multirow[b]{2}{*}{ Serum } & \multicolumn{3}{|c|}{ Colony types* } \\
\hline & & Granulocytes & $\begin{array}{l}\text { Monocytes/ } \\
\text { macrophages }\end{array}$ & $\begin{array}{l}\text { Granulocytes/ } \\
\text { macrophages }\end{array}$ \\
\hline- & $\begin{array}{l}+ \\
-\end{array}$ & $\begin{array}{l}32 \pm 3 \\
12 \pm 2\end{array}$ & $\begin{array}{l}40 \pm 5 \\
17 \pm 2\end{array}$ & $\begin{array}{l}36 \pm 5 \\
12 \pm 3\end{array}$ \\
\hline IGF-I/Sm-C ( $2 \mathrm{ng} / \mathrm{ml})$ & $\begin{array}{l}+ \\
-\end{array}$ & $\begin{array}{l}49 \pm 5 \\
17 \pm 2\end{array}(P<0.05)$ & $\begin{array}{l}37 \pm 2 \\
16 \pm 2\end{array}$ & $\begin{array}{l}34 \pm 2 \\
12 \pm 1\end{array}$ \\
\hline IGF-I/Sm-C (6 ng/ml) & $\begin{array}{l}+ \\
-\end{array}$ & $\begin{array}{l}70 \pm 3 \\
29 \pm 3\end{array}(P<0.001)$ & $\begin{array}{l}37 \pm 6 \\
16 \pm 3\end{array}$ & $\begin{array}{l}35 \pm 4 \\
13 \pm 2\end{array}$ \\
\hline IGF-I/Sm-C (200 ng/ml) & $\begin{array}{l}+ \\
-\end{array}$ & ${ }_{33 \pm 3}^{72 \pm 7}(P<0.001)$ & $\begin{array}{l}40 \pm 3 \\
15 \pm 2\end{array}$ & $\begin{array}{l}37 \pm 6 \\
14 \pm 2\end{array}$ \\
\hline hGh $(50 \mathrm{ng} / \mathrm{ml})$ & $\begin{array}{l}+ \\
-\end{array}$ & $\begin{array}{l}43 \pm 5(P<0.05) \\
18 \pm 3(P<0.03)\end{array}$ & $\begin{array}{l}39 \pm 6 \\
15 \pm 3\end{array}$ & $\begin{array}{l}40 \pm 4 \\
13 \pm 2\end{array}$ \\
\hline $\mathrm{hGH}(150 \mathrm{ng} / \mathrm{ml})$ & $\begin{array}{l}+ \\
-\end{array}$ & $\begin{array}{l}56 \pm 5(P<0.001) \\
22 \pm 4(P<0.05)\end{array}$ & $\begin{array}{l}44 \pm 6 \\
16 \pm 3\end{array}$ & $\begin{array}{l}36 \pm 4 \\
15 \pm 2\end{array}$ \\
\hline hGH $(250 \mathrm{ng} / \mathrm{ml})$ & $\begin{array}{l}+ \\
-\end{array}$ & ${ }_{29 \pm 4}^{67 \pm 7}(P<0.001)$ & $\begin{array}{l}38 \pm 3 \\
15 \pm 2\end{array}$ & $\begin{array}{l}40 \pm 5 \\
15 \pm 2\end{array}$ \\
\hline IGF-I/Sm-C $(2 \mathrm{ng} / \mathrm{ml})+\mathrm{hGH}(50 \mathrm{ng} / \mathrm{ml})$ & $\begin{array}{l}+ \\
-\end{array}$ & $\begin{array}{l}53 \pm 7(P<0.03) \\
23 \pm 4(P<0.005)\end{array}$ & $\begin{array}{l}34 \pm 4 \\
15 \pm 3\end{array}$ & $\begin{array}{l}43 \pm 6 \\
14 \pm 3\end{array}$ \\
\hline IGF-I/Sm-C $(200 \mathrm{ng} / \mathrm{ml})+\mathrm{hGH}(250 \mathrm{ng} / \mathrm{ml})$ & $\begin{array}{l}+ \\
-\end{array}$ & ${ }_{30 \pm 4}^{74 \pm 6}(P<0.001)$ & $\begin{array}{l}35 \pm 3 \\
15 \pm 2\end{array}$ & $\begin{array}{l}41 \pm 7 \\
15 \pm 2\end{array}$ \\
\hline
\end{tabular}

Data are given as colony frequency per $10^{5}$ cells. Cultures were stimulated with 200 pM human recombinant GM-CSF. Results represent the mean \pm SD of three independent experiments, performed in triplicates. + , Supplemented with $10 \% \mathrm{FCS} ;-$, serum free. ${ }^{*}$ Colony types were calculated from the percentage of 100 to 200 typed colonies. 
Table III. Effect of IGF-I/Sm-C and hGH on In Vitro Granulocytic Maturation

\begin{tabular}{|c|c|c|c|c|c|}
\hline \multirow[b]{2}{*}{ Additive } & \multirow[b]{2}{*}{ Serum } & \multicolumn{4}{|c|}{ Percent cell type* } \\
\hline & & Promyelocytes & Myelocytes & Metamyelocytes & Band/segment \\
\hline \multirow[t]{2}{*}{ - } & + & $4 \pm 1$ & $27 \pm 2$ & $35 \pm 7$ & $34 \pm 6$ \\
\hline & - & 0 & $25 \pm 3$ & $37 \pm 6$ & $38 \pm 4$ \\
\hline IGF-I/Sm-C (2 ng/ml) & $\begin{array}{l}+ \\
-\end{array}$ & $\begin{array}{l}0 \\
0\end{array}$ & $\begin{array}{l}6 \pm 2 \\
9 \pm 2\end{array}(P<0.001)$ & $\begin{array}{l}39 \pm 9 \\
36 \pm 8\end{array}$ & ${ }_{55 \pm 6}^{55 \pm 7}(P<0.03)$ \\
\hline IGF-I/Sm-C (6 ng/ml) & $\begin{array}{l}+ \\
-\end{array}$ & $\begin{array}{l}1 \pm 1 \\
2 \pm 1\end{array}$ & $\begin{array}{c}8 \pm 2(P<0.001) \\
14 \pm 3(P<0.03)\end{array}$ & $\begin{array}{l}40 \pm 8 \\
34 \pm 6\end{array}$ & ${ }_{50 \pm 4}^{51 \pm 6}(P<0.03)$ \\
\hline IGF-I/Sm-C (200 ng/ml) & $\begin{array}{l}+ \\
-\end{array}$ & $\begin{array}{c}2 \pm 1 \\
0\end{array}$ & $\begin{array}{r}9 \pm 2 \\
10 \pm 2\end{array}(P<0.001)$ & $\begin{array}{l}39 \pm 11 \\
37 \pm 1\end{array}$ & $\begin{array}{l}50 \pm 5 \\
53 \pm 6\end{array}(P<0.03)$ \\
\hline $\mathrm{hGH}(50 \mathrm{ng} / \mathrm{ml})$ & $\begin{array}{l}+ \\
-\end{array}$ & $\begin{array}{l}2 \pm 1 \\
2 \pm 1\end{array}$ & $\begin{array}{l}12 \pm 2(P<0.001) \\
14 \pm 2(P<0.03)\end{array}$ & $\begin{array}{l}39 \pm 6 \\
32 \pm 4\end{array}$ & ${ }_{52 \pm 4}^{47 \pm 4}(P<0.05)$ \\
\hline $\mathrm{hGH}(150 \mathrm{ng} / \mathrm{ml})$ & $\begin{array}{l}+ \\
-\end{array}$ & $\begin{array}{c}3 \pm 2 \\
0\end{array}$ & $\begin{array}{r}14 \pm 4 \\
8 \pm 2\end{array}(P<0.001)$ & $\begin{array}{l}37 \pm 6 \\
41 \pm 9\end{array}$ & ${ }_{51 \pm 6}^{46 \pm 4}(P<0.05)$ \\
\hline hGH (250 ng/ml) & $\begin{array}{l}+ \\
-\end{array}$ & $\begin{array}{c}0 \\
1 \pm 1\end{array}$ & $\begin{array}{l}11 \pm 4 \\
13 \pm 3\end{array}(P<0.001)$ & $\begin{array}{l}40 \pm 9 \\
33 \pm 7\end{array}$ & $\begin{array}{l}49 \pm 6(P<0.05) \\
53 \pm 4(P<0.03)\end{array}$ \\
\hline
\end{tabular}

Data represent the mean \pm SD of three independent experiments, performed in duplicates. $\quad+$, Supplemented with $10 \%$ FCS; -, serum free.

* Estimated by differential counts of 200 myeloid cells.

mained unchanged. The effect observed was virtually the same in both the presence and absence of serum.

Effect of IGF-I/Sm-C and hGH on granulocytic maturation in vitro. The effect of IGF-I/Sm-C and hGH on cellular maturation towards granulocytes was evaluated in 7-d suspension cultures of marrow mononuclear cells, in both the presence and the absence of serum. As compared with control cultures supplemented with GM-CSF alone (Table III), a significant decrease in the frequency of immature granulocytes (myelocytes) and an $\sim 1.5$-fold increase in the percentage of mature granulocytes (band/segment) was observed in the presence of IGF-I/Sm-C (2-200 ng/ml) and hGH $(50-250 \mathrm{ng} / \mathrm{ml})$. The frequency of metamyelocytes was not significantly altered. Differential counts of myeloid cells in control cultures supplemented with GM-CSF did not differ significantly from values of starting (day 0 ) marrow mononuclear cells (data not shown). The percentage of monocytes in all assay cultures did not differ from controls $(14 \pm 2 \%)$. The viability in the har-

Table IV. Effect of IGF-I/Sm-C and hGH on Myeloid Colony Formation by Nonadherent Target Marrow Cells

\begin{tabular}{lll}
\hline & \multicolumn{2}{c}{ Colonies per $10^{5}$ cells } \\
\cline { 2 - 3 } \multicolumn{1}{c}{ Additive } & \multicolumn{1}{c}{ Total frequency } & Granulocyte colonies* \\
\hline- & $70 \pm 6$ & $23 \pm 3$ \\
IGF-I $/ \mathrm{Sm}-\mathrm{C}(6 \mathrm{ng} / \mathrm{ml})$ & $90 \pm 4(P<0.01)$ & $50 \pm 5(P<0.001)$ \\
IGF-I $/ \mathrm{Sm}-\mathrm{C}(200 \mathrm{ng} / \mathrm{ml})$ & $95 \pm 7(P<0.01)$ & $53 \pm 6(P<0.001)$ \\
hGH $(50 \mathrm{ng} / \mathrm{ml})$ & $69 \pm 6$ & $22 \pm 2$ \\
hGH $(250 \mathrm{ng} / \mathrm{ml})$ & $74 \pm 7$ & $23 \pm 3$
\end{tabular}

Cultures were stimulated with 200 pM human recombinant GMCSF. No colonies were detected in the absence of GM-CSF. Results represent mean $\pm \mathrm{SD}$ of three independent experiments, performed in duplicates.

* Calculated from the percentage of 200 typed colonies. vested cell suspensions, determined by trypan blue exclusion, was $>85 \%$ in all cultures.

Role of adherent cells in enhancement of human marrow granulopoiesis. To evaluate whether the enhancement of granulopoiesis by IGF-I/Sm-C and hGH may be mediated by marrow accessory cells, the effect of both peptides was assayed in cultures that had been depleted of marrow adherent cells. Whereas IGF-I/Sm-C induced a greater than twofold augmentation in the total numbers of granulocyte colonies (Table IV), hGH failed to exert this effect in cultures of nonadherent, target marrow cells. In all cases, the total numbers of monocyte/macrophage and mixed granulocyte/macrophage colonies did not differ from control values $(26 \pm 3$ and $21 \pm 3$ colonies $/ 10^{5}$ cells, respectively).

Whereas IGF-I/Sm-C induced a significant decrease in myelocytes and an increase in mature granulocytes in suspension cultures depleted of marrow adherent cells (Table V), this phenomenon was not detected in cultures supplemented with

Table V. Effect of IGF-I/Sm-C and hGH on Granulocytic Maturation in Suspension Cultures of Nonadherent Target Marrow Cells

\begin{tabular}{lll}
\hline & \multicolumn{2}{c}{ Percent cell type* } \\
\cline { 2 - 3 } \multicolumn{1}{c}{ Additive } & \multicolumn{1}{c}{ Myelocytes } & \multicolumn{1}{c}{ Band/segment } \\
\hline- & $19 \pm 2$ & $46 \pm 5$ \\
IGF-I $/ \mathrm{Sm}-\mathrm{C}(6 \mathrm{ng} / \mathrm{ml})$ & $13 \pm 3(P<0.05)$ & $59 \pm 6(P<0.05)$ \\
IGF-I $/ \mathrm{Sm}-\mathrm{C}(200 \mathrm{ng} / \mathrm{ml})$ & $11 \pm 2(P<0.01)$ & $62 \pm 6(P<0.03)$ \\
hGH $(50 \mathrm{ng} / \mathrm{ml})$ & $24 \pm 4$ & $42 \pm 4$ \\
hGH $(250 \mathrm{ng} / \mathrm{ml})$ & $24 \pm 4$ & $44 \pm 4$
\end{tabular}

Results represent the mean \pm SD of three independent experiments, performed in duplicates.

* Estimated by differential counts of 200 myeloid cells. 
Table VI. Abrogation of hGH-induced Enhancement of Granulocyte Colony Formation by an Anti-IGF-I/Sm-C Receptor Antibody, $\alpha I R-3$

\begin{tabular}{|c|c|c|c|c|}
\hline \multirow[b]{3}{*}{ Additive } & \multicolumn{4}{|c|}{ Colonies per $10^{5}$ cells } \\
\hline & \multicolumn{2}{|c|}{ Total colony frequency } & \multicolumn{2}{|c|}{ Granulocyte colonies } \\
\hline & $-\alpha$ IR-3 & $+\alpha \mathrm{IR}-3^{*}$ & $-\alpha \mathrm{IR}-3$ & $+\alpha I R-3$ \\
\hline hGH (250 ng/ml) & $146 \pm 8(P<0.001)$ & $95 \pm 10$ & $86 \pm 10(P<0.001)$ & $37 \pm 6$ \\
\hline IGF-I/Sm-C $(200 \mathrm{ng} / \mathrm{ml})$ & $143 \pm 12(P<0.001)$ & $108 \pm 13$ & $82 \pm 12(P<0.001)$ & $45 \pm 6$ \\
\hline- & $95 \pm 10$ & $101 \pm 12$ & $36 \pm 6$ & $44 \pm 7$ \\
\hline
\end{tabular}

Cultures were stimulated with $200 \mathrm{pM}$ human recombinant GM-CSF. hGH and IGF-I/Sm-C were added $2 \mathrm{~h}$ after the initiation of culture. Results represent the mean $\pm \mathrm{SD}$ of three independent experiments, performed in duplicates. *Added at a final concentration of $15 \mu \mathrm{g} / \mathrm{ml}$.

hGH. The percentage of promyelocytes and myelocytes did not vary from control values ( $1 \pm 1$ and $34 \pm 6 \%$, respectively).

Role of IGF-I/Sm-C as mediator of $h G H$. The possibility that augmentation of marrow granulopoiesis by $\mathrm{hGH}$ may be mediated via IGF-I/Sm-C was investigated by the use of a monoclonal antibody ( $\alpha \mathrm{IR}-3$ ) directed against IGF-I/Sm-C receptors.

$\alpha$ IR-3 abrogated the enhancement of granulocyte colony formation by hGH (Table VI) as well as its effect on granulocytic maturation in suspension cultures (Table VII). The enhancement of human marrow granulopoiesis by IGF-I/Sm-C was also eliminated by $\alpha$ IR-3, whereas colony growth and cellular maturation in control cultures remained unchanged. The presence of $\alpha$ IR-3 did not influence the total numbers of monocyte/macrophage and granulocyte/macrophage colonies in agar or the percentage of immature granulocytes (promyelocytes and myelocytes) in suspension cultures.

\section{Discussion}

Primarily regulated by specific CSFs (21), human hemopoiesis in vitro is also modulated by a variety of hormones and growth peptides (22-24). The growth-promoting effects of IGFs and hGH in human erythropoiesis have been extensively investigated and described $(13-15,25)$. The findings presented in this study demonstrate that IGF-I/Sm-C and hGH enhance the in vitro proliferation and maturation of human myeloid progenitor cells, as well.

IGF-I/Sm-C and hGH were found to enhance the formation of colonies in cultures of human marrow myeloid progenitors through a growth-promoting effect on granulopoiesis.

Table VII. Abrogation of hGH-induced Enhancement of Granulocyte Maturation by $\alpha I R-3$

\begin{tabular}{|c|c|c|c|}
\hline \multirow[b]{2}{*}{ Additive } & \multirow[b]{2}{*}{$\alpha$ IR-3* } & \multicolumn{2}{|c|}{ Percent cell type } \\
\hline & & Myelocytes & Band/segment \\
\hline hGh $(250 \mathrm{ng} / \mathrm{ml})$ & $\begin{array}{l}+ \\
-\end{array}$ & $\begin{array}{l}20 \pm 2 \\
12 \pm 2(P<0.001)\end{array}$ & $\begin{array}{l}35 \pm 6 \\
52 \pm 7(P<0.03)\end{array}$ \\
\hline $\begin{array}{l}\text { IGF-I/Sm-C } \\
(200 \mathrm{ng} / \mathrm{ml})\end{array}$ & $\begin{array}{l}+ \\
-\end{array}$ & $\begin{array}{l}18 \pm 3 \\
11 \pm 3(P<0.001)\end{array}$ & $\begin{array}{l}39 \pm 5 \\
55 \pm 6(P<0.03)\end{array}$ \\
\hline - & $\begin{array}{l}+ \\
-\end{array}$ & $\begin{array}{l}22 \pm 2 \\
26 \pm 3\end{array}$ & $\begin{array}{l}34 \pm 4 \\
37 \pm 5\end{array}$ \\
\hline
\end{tabular}

hGH and IGF-I/Sm-C were added $2 \mathrm{~h}$ after the initiation of culture. Results represent the mean \pm SD of three independent experiments, performed in duplicates. +, Present; -, absent.

* Added at a final concentration of $15 \mu \mathrm{g} / \mathrm{ml}$.
Although our findings are at variance with a previous study claiming no effect of hGH on colony formation in cultures of human marrow GM-CFU (14), the phenomenon detected by us may have been masked by the presence of high concentrations $(30 \%)$ of FCS, as serum is known to contain inhibitors of granulopoiesis $(26,27)$. A possible minor contribution of such inhibitors to our serum-supplemented (10\% FCS) cultures is suggested by the similar effect of limiting doses of IGF-I/Sm-C on marrow granulocyte colony formation in both serum-free and serum-supplemented cultures, the latter containing detectable $(11 \mathrm{mU} / \mathrm{ml})$ IGF-I/Sm-C.

While serum-free cultures for studies of the regulation of hemopoiesis may exclude the interaction between a certain growth-promoting substance and any unknown variables (e.g., hormones, growth factors) that serum may contain, elucidation of the mechanism whereby such a substance exerts its effect upon hemopoietic progenitors is still complicated by the presence of accessory cells (e.g., fibroblasts, endothelial cells, monocytes, lymphocytes) within the bone marrow (28). Indeed, recent studies have shown that the enhancement of human marrow erythropoiesis in vitro by thyroid hormones is mediated indirectly by augmenting the release of soluble hemopoietic-like regulator molecules from accessory (probably B lymphocytes) marrow cells (29). Our findings have shown that IGF-I/Sm-C and hGH do not induce the production of specific hemopoietic regulators by bone marrow accessory cells (29-32), nor do they act as GM-CSF, since they do not stimulate the formation of colonies when added to culture in the absence of this regulator. However, the requirement of marrow adherent cells for enhancement of granulopoiesis by hGH, but not by IGF-I/Sm-C, revealed an indirect growth-promoting effect of the former on human marrow myeloid precursors. The possibility that marrow monocytes are the target cells that mediate the effect of hGH is suggested by their high frequency $(89 \pm 3 \%)$ within the adherent cell population.

The functional link between IGF-I/Sm-C and hGH has been a subject of extensive investigation. IGF-I/Sm-C is considered to be the growth-promoting mediator of growth hormone (5), and although the liver was first singled out as a target for the stimulation of somatomedin production by growth hormone (33), it is now recognized that a variety of cells and tissues can respond to hGH by somatomedin synthesis, both in vivo $(5,34)$ and in vitro $(35,36)$. Our in vitro findings of abolishment of the growth-promoting effects of hGH on marrow myeloid progenitors by the anti-IGF-I/Sm-C receptor monoclonal antibody $\alpha$ IR-3 (20), provide strong evidence that IGF-I/Sm-C serves as the mediator of hGH among hemopoie- 
tic progenitor cells as well. This is further supported by the strikingly similar effect of hGH and IGF-I/Sm-C on the growth and maturation of human marrow myeloid progenitors, as well as the combined effect observed at limiting and maximal concentrations of both peptides. That IR-3 did not alter in vitro granulopoiesis in control cultures indicates that the marrow cells themselves do not produce significant levels of IGF-I/Sm-C under basal conditions.

The effective concentrations of IGF-I/Sm-C for the phenomenon described in this investigation are within the physiologic range of normal serum concentrations (37) and do not differ in order of magnitude from those described for human and murine erythroid progenitors $(13,15)$. Maximal growthpromoting effects of hGH upon granulocyte colony formation were detected only at higher than physiologic concentrations. These findings may be explained by the use of culture conditions which, although appropriate for the growth of hemopoietic progenitors, may not be suitable for optimal functional expression of marrow accessory cells. Although the role of marrow adherent cells in hGH-induced enhancement of erythropoiesis in vitro has yet to be elucidated, the effective doses of hGH for granulocyte colony formation are in accordance with those recently described for erythroid progenitors by Claustres et al. (13).

IGF-I/Sm-C and hGH enhanced the maturation of morphologically recognizable granulocytic progenitors in suspension cultures of human marrow cells. We have recently found that these peptides also induced granulocytic maturation in suspension cultures of marrow cells from a patient with acute promyelocytic leukemia (manuscript in preparation). Although preliminary, these findings nevertheless warrant further extensive in vitro investigation as to the possible clinical application of IGF-I/Sm-C (or hGH) in the enhancement of myeloid progenitor cell maturation in neutropenic patients or in leukemia and preleukemia, alone or in concert with other maturation-inducing agents and drugs (38).

\section{Acknowledgments}

We are grateful to Dr. L. Fryklund (KabiVitrum) for her generous supply of biosynthetic IGF-I/Sm-C, to Dr. J. Gasson for kindly providing human recombinant GM-CSF, and to Dr. J. J. Van Wyk for kindly supplying anti-IGF-I/Sm-C monoclonal antibody, $\alpha$ IR-3.

This work was supported by the Mitchell-Copp Research Fund.

\section{References}

1. Blundel, T. L., and R. E. Humbel. 1980. Hormone families: pancreatic hormones and homologous growth factors. Nature (Lond.). 287:781-787.

2. Van Wyk, J. J. 1984. The somatomedins: biological actions and physiologic control mechanisms. In Hormonal Proteins and Peptides. Vol. XII. C. H. Li, editor. Academic Press, Inc., New York. 82-120.

3. Jansen, M., F. M. A. van Schaik, T. Ricker, B. Bullock, D. E. Woods, K. H. Gabbay, A. L. Nussbaum, J. S. Sussenbach, and J. L. Van den Brande. 1983. Sequence of cDNA encoding human insulinlike growth factor precursor. Nature (Lond.). 306:609-611.

4. Bell, G. I., J. P. Merryweather, R. Sanchez-Pescador, M. M. Stempien, L. Priestly, J. Scott, and L. B. Rall. 1984. Sequence of a cDNA clone encoding human pre-proinsulin-like growth factor II. Nature (Lond.). 310:775-777.

5. D'Ercole, A. J., A. D. Stiles, and L. E. Underwood. 1984. Tissue concentrations of somatomedin C: further evidence for multiple sites of synthesis and paracrine or autocrine mechanisms of action. Proc. Natl. Acad. Sci. USA. 81:935-939.

6. Zapf, J., E. Schoenle, and E. R. Froesch. 1978. Insulin-like growth factors I and II: some biological actions and receptor binding characteristics of two purified constituents of nonsuppressive insulinlike activity of human serum. Eur. J. Biochem. 87:285-296.

7. Marshall, R. N., L. E. Underwood, S. J. Voina, D. B. Foushee, and J. J. Van Wyk. 1974. Characterization of the insulin and somatomedin C receptors in human placental cell membranes. J. Clin. Endocrinol. Metab. 39:283-292.

8. Rechler, M. M., S. P. Nissley, J. M. Podskalny, A. C. Moses, and L. Fryklund. 1977. Identification of a receptor for somatomedin-like polypeptides in human fibroblasts. J. Clin. Endocrinol. Metab. 44:820-831.

9. Furlanetto, R. W., and J. N. DiCarlo. 1984. Somatomedin C receptors and growth effects in human breast cells maintained in longterm tissue culture. Cancer Res. 44:2122-2128.

10. Lee, P. D. K., R. G. Rosenfeld, R. L. Hintz, and S. D. Smith. 1986. Characterization of insulin, insulin-like growth factors I and II, and growth hormone receptors on human leukemic lymphoblasts. $J$. Clin. Endocrinol. Metab. 62:28-35.

11. Polychronakos, C., H. J. Guyda, and B. I. Posner. 1983. Receptors for the insulin-like growth factors on human erythrocytes. $J$. Clin. Endocrinol. Metab. 57:436-438.

12. Pepe, M., N. Ginzton, P. Lee, R. L. Hintz, and P. L. Greenberg. 1986. Insulin (INS) and insulin-like growth factor (IGFI, II) receptors on human myeloid leukemic cells. Exp. Hematol. (NY). 14:428. (Abstr.)

13. Claustres, M., P. Chatelain, and C. Sultan. 1986. Comparative effects of human growth hormone (hGH) and insulin-like growth factor I/somatomedin C (IGF-I/Sm-C) on erythropoietic cultures from normal children. 1986. Pediatr. Res. 20:1191. (Abstr.)

14. Golde, D. W., N. Bersch, and C. H. Li. 1976. Growth hormone: species-specific stimulation of erythropoiesis in vitro. Science (Wash. DC). 196:1112-1113.

15. Golde, D. W. 1979. In vitro effects of growth hormones. In Growth Hormones and Other Biologically Active Peptides. A. Pecile and E. E. Muller, editors. Excerpta Medica, Amsterdam. 52-62.

16. Guilbert, L. J., and N. N. Iscove. 1976. Partial replacement of serum by selenite, transferrin, albumin, and lecithin in haemopoietic cell cultures. Nature (Lond.). 263:594-595.

17. Golde, D. W., S. G. Quan, and J. J. Cline. 1978. Human T-lymphoblast cell line producing colony-stimulating activity. Blood. 52:1068-1072.

18. Tomonaga, M., D. W. Golde, and J. C. Gasson. 1986. Biosynthetic (recombinant) human granulocyte/macrophage colony-stimulating factor: effect on normal bone marrow and leukemic cell lines. Blood. 67:31-36.

19. Phillips, P. G., G. Chikkappa, and P. S. Bunson. 1983. A triple stain technique to evaluate monocyte, neutrophil, and eosinophil proliferation in soft agar cultures. Exp. Hematol. (NY). 11:10-17.

20. Kull, F. C., S. Jacobs, Y.-F. Su, M. E. Svoboda, P. Cuatrecasas, and J. J. Van Wyk. 1983. Monoclonal antibodies to receptors for insulin and somatomedin C. J. Biol. Chem. 258:6561-6566.

21. Metcalf, D. 1985. The granulocyte/macrophage colony-stimulating factors. Science (Wash. DC). 229:16-22.

22. Golde, D. W., and M. J. Cline. 1978. Hormonal interactions with hematopoietic cells in vitro. Transplant. Proc. 10:95-97.

23. Dainiak, N., G. Davies, M. Kalmanti, J. Lawler, and V. Kulkarni. 1983. Platelet-derived growth factor promotes proliferation of erythropoietic progenitor cells in vitro. J. Clin. Invest. 71:1206-1214.

24. Michalevicz, R., G. E. Francis, G. Price, and A. V. Hoffbrand. 1985. The role of platelet-derived growth factor in human pluripotent progenitor (CFU-GEMM) growth in vitro. Leuk. Res. 9:399-405.

25. Dainiak, N., and S. Kreczko. 1985. Interactions of insulin, insulin-like growth factor II, and platelet-derived growth factor in erythropoietic culture. J. Clin. Invest. 76:1237-1242. 
26. Chan, S. H., D. Metcalf, and E. R. Stanley. 1971. Stimulation and inhibition by normal serum of colony formation in vitro by bone marrow cells. Br. J. Haematol. 20:329-341.

27. Baker, F. L., and P. R. Galbraith. 1979. Mechanism of action of serum factors that regulate granulopoiesis in vitro: possible physiologic role of serum-inhibiting activity. Blood. 53:304-312.

28. Lichtman, M. A. 1981. The ultrastructure of the hematopoietic environment of the marrow: a review. Exp. Hematol. (NY). 9:391397.

29. Dainiak, N., D. Sutter, and S. Kreczko. 1986. L-Triiodothyroxine augments erythropoietic growth factor release from peripheral blood and bone marrow leukocytes. Blood. 68:1289-1297.

30. Greenberg, P. L., B. Mara, and P. Heller. 1978. Marrow adherent cell colony-stimulating activity production in acute myeloid leukemia. Blood. 52:362-378.

31. Quesenberry, P. J., and M. A. Grimbone. 1980. Vascular endothelium as a regulator of granulopoiesis: production of colony-stimulating activity by cultured human endothelial cells. Blood. 56:10601067.

32. Broudy, V., K. S. Zuckerman, S. Jetmalain, J. H. Fitchen, and G. C. Bagby, Jr. 1986. Monocytes stimulate fibroblastoid bone marrow stromal cells to produce multilineage haemopoietic growth factors. Blood. 68:530-535.

33. Phillips, L. S., A. C. Herington, I. E. Karl, and W. H. Daughaday. 1976. Comparison of somatomedin activity in perfusates of normal and hypophysectomized rat livers with and without added growth hormone. Endocrinology. 98:606-614.

34. Davoren, J. B., and A. J. W. Hsueh. 1986. Growth hormone increases ovarian levels of immunoreactive somatomedin C/insulinlike growth factor I in vivo. Endocrinology. 118:888-890.

35. Clemmons, D. R., L. E. Underwood, and J. J. Van Wyk. 1981. Hormonal control of immunoreactive somatomedin production by cultured human fibroblasts. J. Clin. Invest. 67:10-18.

36. Ritzen, E. M. 1983. Chemical messengers between Sertoli cells and neighbouring cells. J. Steroid Biochem. 19:499-504.

37. Zapf, J., H. Walker, and E. R. Froesch. 1981. Radioimmunological detection of insulin-like growth factors I and II in normal subjects and in patients with growth disorders and extrapancreatic tumor hypoglycemia. J. Clin. Invest. 68:1321-1330.

38. Koeffler, P. 1983. Induction of differentiation of human acute myelogenous leukemia cells: therapeutic implications. Blood. 62:709_ 721. 